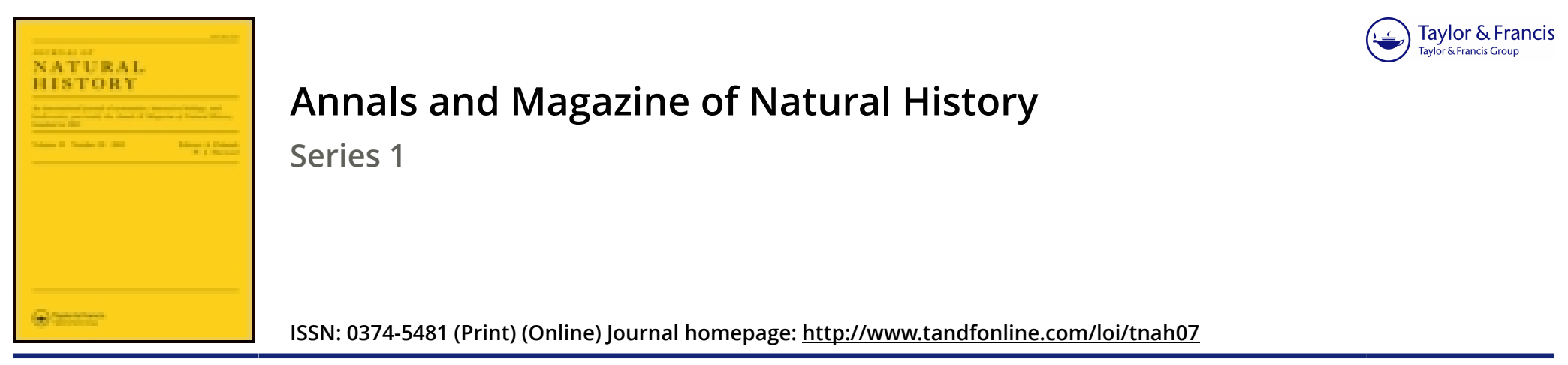

\title{
XLVII.-Remarks on a Collection of Australian Drawings of Birds, the Property of the Earl of Derby
}

\author{
H. E. Strickland Esq., M.A.
}

To cite this article: H. E. Strickland Esq., M.A. (1843) XLVII.-Remarks on a Collection of Australian Drawings of Birds, the Property of the Earl of Derby, Annals and Magazine of Natural History, 11:71, 333-338, DOI: 10.1080/03745484309445312

To link to this article: http://dx.doi.org/10.1080/03745484309445312

曲 Published online: 04 Dec 2009.

Submit your article to this journal $\pi$

View related articles ¿ 
XLVII.-Remarks on a Collection of Australian Drawings of Birds, the Property of the Earl of Derby. By II. L. STrICKLAND, Esq., M.A.

IN the March Number of the 'Annals of Nat. Iist.' Mr. G. R. Gray has given a list of certain Australian birds long since described by Latham, but which, from the brevity and incompleteness of that author's descriptions, have remained till now in much obscurity. By the aid of the original drawings, from which alone Latham compiled his descriptions, Mr. Gray has been enabled to refer the greater part of these hitherto doubtful species to their true place in the modern system, and by applying the "law of priority" to their specific names has done an act of justice to the father of British ornithologists.

Having had the pleasure of co-operating with Mr. Gray in comparing these drawings with specimens in the British Museum, and having then acquiesced in most of the conclusions to which he arrived, I should not have now referred to them, were it not that the Earl of Derby has kindly permitted me to take these drarrings to my own residence, and by a careful comparison of them with specimens in my collection, I have obtained a few additional results.

Mr. Gould has also examined these drawings with much attention, and has communicated his remarks upon them, which, with his permission, I have inserted in the present notice, distinguishing them by the initials J. G.

These water-colour drawings, comprised in three folio volumes, are 225 in number, the first being a landscape in Norfolk Island, the next ten are mammalia, and the rest birds. There is no title-pnge, date or artist's name, but the backs are lettered "New South Wales Drawings," and there is every reason to beliese that the whole of them were made in the Australian regions. It has been supposed that the artist was John White, author of the 'Voyage to New South Wales,' 4to, London, 1790, soon after which date they came into possession of Mr. A. B. Lambert. Mr. Gould however remarks, "this is probably a mistake; they were perhaps made by some convict. Mr. Lambert told Mr. Prince, upon showing him the drawings some time before his death, that they were made by an artist in the colony for one of the governors, by whom they werc presented to MIr. Lambert. I an strengthened in this opinion by observing among them many of the denizens of the penal settlement of Norfolk Island, a part never I believe visited by White."

In 1800 they were borrowed by Dr. Latham, as appears from an autograph letter from him to Mr. Lambert, inserted 
into the first volume. It was this circumstance which conferred on these drawings a far greater value than they would intrinsically have possessed. Dr. Latham not only wrote on cach drawing with his own hand the name which he intended the species to retain, but drew up from these designs a great number of original specific descriptions, which he published for the first time in the second Supplement of his ' Synopsis,' 4to, London, 1802, and which are repeated in his 'Gencral History of Birds,' and in the works of Shaw, Vicillot and other compilers. But innsmuch as many of the drawings are but rude and unscientific copies of nature, and the descriptions are often very vague copics of the drawings, these nominal species have hitherto lain in great obscurity, which will now be in great measure removed by the fortunate discovery, at Mr. Lambert's death, of the original designs.

The plates $121,122,126,127,129,131,134,136$ and 139 of Latham's second Supplement are copies, more or less exact, of some of these drawings; and it further appears that a $\mathbf{M}$. Francillon, a French artist, copied others of them early in the present century, as some of the plates in Vieillot's 'Öiseaux Dorées,' said to be from M. Francillon's designs, are manifest copies from this collection. From that time till very recently the "New South Wales Drawings" remained in oblivion, to the no small inconvenience of the science, for had Messrs. Vigors and Horsfield and other writers on Australian ornithology had an opportunity of consulting them, it would have saved us many superfluous synonyms and cleared up many difficultics.

These remarks, it is hoped, will prove the great value of original drawings when they have been used as the basis of specific descriptions. How much useless lumber was removed from zoolory by the valuable memoir of Lichtenstein on the original designs for Marcgrave's 'History of Brazil,' now preserved at Berlin! (See Oken's 'Isis,' 1820.) And Mr. Gray would confer an cqual boon if he would give us a catalogue raisonnée of the yet unpublished drawings made by Forster during Capt. Cook's voyage, and preserved in the British Museum. There are also numerous unascertained species described by Latham from drawings once belonging to Lady Impey, Gen. Davies, and other persons, which, if they could be now discovered, would prove of the utmost value to modern science. Let me hope that these observations may aid in bringing some of these lost documents to light, and in submitting them to the criticisms of zoologists.

I now proceed to make some specific remarks by way of a commentary and supplement to Mr. Gray's paper, premising 
that the determination of many of these species is rendered difficult by the rudeness of the designs, and by the changes which some of the colours have undergone, especinlly the whites, which being metallic colours have become oxydized, and are now changed to black. Another difficulty arises from some of the birds being drawn of the natural size and others reduced, without any indication when this is the case, so that the dimensions given by Latham from the drawings are often faulty. Hence, after all the pains bestower by Mr. G. R. Gray, Mr. Gould, and myself, some few of the drawings still fail to be identified with any known species. These may either represent true species unknomn to modern science, or they may possibly be, as Mr. Gould conjectures, mere inventions of the artist.

Page 189 of the present vol. After "FaLco nisus, Lath.," insert $v a r . \delta$. (This bird is the Accipiler torquatus, not Astur approximans, J. G.) Also note that the larger species, Astur approximans of Vigors and Gould, is unquestionably a true Accipiter and not an Astur. (The true Falco radiatus of Latham is also not an Astur but an $A c$ cipiter, J. G.).

(FaLco lunulatus, Lath., is perhaps a young Ieracidea, J. G.*)

(Lasius robustus, Lath., represents one of the numerous rarieties of plumage of Graucalus mentalis. It must now I suppose be called Graucalus robustus, J. G.)

LAsius crectus, Lath., judging from the figure, is more like a $\mathrm{Ma}$ lurus than a Falcunculus, but $\mathrm{I}$ am unacquainted with any species like it.

P. 190. Convus versicolor, Iath., is a true species of Strepera, of a gray colour, allied in form and size to Strepera graculina. I possess a specimen, and Mr. Gould has shot it in New South Wales. The name versicolor being decidedly erroneous, Mr. Gould proposes to call it Strepera cinerea.

Convus cyanoleucus, Lath. As this bird was also very accurately described by Latham in his second Supplement under the name of Gracula picata, and as the name picata is more correctly descriptive than cyanoleuca, I should prefer making the permanent designation of the bird Grallina picata (Lath.) rather than Grallina cyanoleuca (Lath.).

For Cuculus phasianus, Lath., read Cucusus phasianinus, Lath., and it should therefore now stand as Centropus phasianinus.

P. 191. (Centura melanops. Lath. Syn. Sup. ii. p. 165. descrip. tion 1, is perhaps the same as Glycyphila fulvifrons, J. G.)

(Certhia melanops, rar. Lath. l.c. description 2, is certainly Glycyphila fuluifrons, J. G.)

* Mr. Gould and I have compared the draming of Falco lunulatus, Lath., with specimens of Ieracidea berigora and Falco fronlatus, Guuld. Though differing from both, it most resembles the leracidea. The name Falco frontatus may' therefore be allowed to stand. 
(CERTHu leucophxa, Lath., is not Glycyphila subocularis as Mr. Gray makes it, but is the Climacteris picummus, Tem., J. G.) 'This is sufficiently evident on comparing the drawing of C. leucophea with Mr. Gould's figure of the female Climacteris picunnus. 'This bird should therefore be designated as Climacteris leucophaa (Lath.).

The Certhia atricapilla of Lath. is figured and described with a white chin, which distinguishes it from the Meliphaga atricapilla of Sir WV. Jardine's 'Illustrations of Ornithology,' ser. 1. pl. 134. f. 1. Mr. Gray unites it to Melithreptus lunulatus (Shaw), but that differs in having a white baud at the back of the head. 'The Certhia atricapilla, Lath., is therefore either a distinct species from both the above, or it may possibly be the young of Jardine's $M$. atricapilla.

Certhia sanguinolenta is probably the female of Myzomela dibapha.

'To the synonyms of Centur dibapha, Lath., add Meliphaga cardinalis, V. and H. (nec Certhia cardinalis, Lath.) and Certhia australasia, Leach.

(Centura canescens, Lath., is perhaps the Colluriocincla cinerea, V. and H., J. G.)

Certura cerulescens, Lath., is the Zostcrops dorsalis, Vig., not the $Z$. tenuirostris, Gould. It is also the Sylvia lateralis of Iatham, and the latter specific name seems preferable to ccerulescens. Add Certhia diluta, Shaw, and Pliledon caruleus, Cuv., to the synonyms of Zosterops lateralis.

Add Certhia xanthotis, Shaw, to the synonyms of Certhia chrysotis, Lath.

P. 192. Mr. Gray makes the Meliphaga auricomis of Vigors, Swainson and Gould, to be distinct from Mruscicapa auricomis, Lath., but I do not see on what grounds. This bird is figured no less than four times over in the "New S. Wales Drawings"-once as Turdus melanops, and again under Latham's MSi. names of Muscicapa australis, Sylvia mystacea, and Muscicapa nove hollandia. These three last references Latham seems to have afterwards incorporated into one species, described in his second Supplement under the name of Muscicapa auriconis. The species should therefore retain the appropriate name of Ptilotis auricomis.

Tundus harmonicus, Lath., is, I have no doubt, a synonym of $\mathrm{Col}$ luriocincla cinerea,Vig., which should therefore stand as Colluriocincla harmonica.

Tundus prasinus, Lath., scems to be the young of Pachyccphala rufiventris (Lath.).

(T'unnus tencbrosus, Lath., is perbaps the young of Artamus sordidus, J. G.)

'To the synonyms of 'Turnus lunulatus, Lath., add Turdus varius, V. and II., and perhaps also T. varius of Horsfield's 'Java.'

(Tunntis fuliginosus, Lath., is Merula nestor, Gould, J. G.), and will now stand as Merula fuliginosa.

(Tundos maxillaris, Lath., is perhaps the Sphecotheres australis, Sw., J. G.)

('Tunve mellinus, Lath., is the young male of Sericulus chrysocephalus, J. G.) 
Loxis bella, Lath., and Loxia nitida, Lath., constitute a welllinown species of Estrilda, which may stand as Estrildla bella, Lath.

(Loxra fascinans, Iath., is my Micrea macroptera, Myiagra macroptera, Vig. I presume it must now be termed Micraca fascinans, J. G.)

P. 193. To the synonyms of Muscicapa pectoralis, Lath., add Turdus lunularis, Steph., and Lanius albicollis, Vieill.

I fecl quite satisfied that Muscicapa cucullata, Lath., is the same as Petroica bicolor, Swains., which should therefore stand as Petroica cucullata (Lath.). Grallina bicolor, V. and H., is another synonym of it.

Muscicapa rhodogastra, Iath., is synonymous with Saxicola rhodinogastra, Drap., and Muscicapa lathami, Vig. It therefore stands as Petroica rhodogastra (Lath.).

Motacines atricapilla, Lath., is possibly the young male of Sericulus chrysocephalus, as it bears some resemblance to the drawing of Turdus mellinus, Iath.

(Mr. Gould considers that the Sycvis sagiltata, Lath. (which is certainly the Anthus minimus, Vig.) will probably rank as the type of a new genus; but for the present we may follow Mr. Gray in calling it Acanthiza śagiltata.)

(SyLvis leucopheca, Lath., is Micreca fascinans (Lath.), J. G.)

(Sycvia versicolor, Lath., is Chrysococcyx lucidus, J. G.) This seems to be the Chrysococcyx plagosus of Mr. Gray, who I belicve regards the true $C$. lacidus of New Zealand as a distinct species. The toes, having been erroneously drawn, induced Latham to make it a Sylcia.

P. 194. The following synonyms refer to Hirundo caudacuta, Lath.: Chatura australis, Steph.; Hirundo fusca, Steph., and Chatura macroptera, Sw.

(Hrnundo pacifica, Lath., is Cypselus australis, Gould, J. G.) It should therefore be designated Cypselus pacificus.

To the synonyms of Capminulgus vittatus, Lath., add Caprimulgus cristatus, White, and Egotheles australis, Sw.

Carrisurgus megacephalus, Iath., appears to be the same as $P_{0}$. dargus stanleyanus, V. and H., and perhaps also Caprimulgus gracilis, Irath.

Coluarba melanoleuca, Lath., is the same as Columba picata, Lath., Columba armillaris, 'Tem., and Columba jamiesoni, Quoy. It will stand as Phaps picata (Lath.), Selby.

A comparison of the original drawing of Charalrius magnirostris, Lath., with a specimen in my collection has convinced me that this bird is no other than GEdicnemus grallarius (Lath.). We have here an instructive example of the mode in which crrors arise and are propagated in natural history. The artist who drew the bird which Latham named Charadrius magnirostris has represented with considerable exactness the plumage of CEdicnemus grallarius, but by throwing too strong a shade into the nasal groore, he led Latham to describe the beak as " very broad, resembling the Tody genus." Next came Illiger, who in his "Prodromus Systematis Mammalium 
et Avium,' published in 1811, had the rashness to found a genus, Burhinus, on Latham's imperfect description of a rude drawing, and the consequence has been that for the last thirty years our systems of ornithology have been haunted by a "Burhinus magnirostris"a cos ct preterea nilil, unknown both to nature and to science. The original drawing which led to all this confusion has now assisted in dispelling it.

Cmanannus griscus, Lath., is I conceive the Charadrius virginiacus, Borkh. (C. marmoratus, Wagl., C. pectoralis, Less., C. affinis, Boié).

The following remarks refer to some additional species of Latham not in Mr. Gray's list :-

Falco ponticerianus, var. Iath., is the Haliastur leucostermus (Gould).

Conrus melanops, Lnth., is the Graucalus melanops. Tem.

Gallisuld porphyrio, var. B. Lath., is Porphyrio melanonotus,

FAlco melanops, Lath., is the Accipiter torquatus, Tem. (Nisus australis, Less.) As the black round the eye which suggested the specific name of melanops seems to be an invention of the artist, I would reject that name on the ground of its serious incorrectness, and retain the later one of torquatus.

FALco albicilla, var. Iath., is the Ichthyaettus leacogaster (Lath.), young (Haliä̈tus sphenurus, Gould).

Fasco clarus, Lath., is perhaps the young of Astur nove hollandic (Lath.).

FALco pacificus, Lath., is perhaps a peculiar state of Milvus isurus, Gould, with the head pure white.

Muscicapa erythrogastra, var. 2. Lath. Syn. Sup. ii. p. 216, is perhaps a new species of Petroica, differing from $P$. multicolor by having a white ejebrow.

(Cucurus fiabelliformis, Lath., may perhaps be the Cuculus cineraceus, Vig., J. G.)

Andex antigone, var. Lath., is Grus antigone (Lin.) (Grus orientalis, Frankl.).

Lawius curvirostris, Lath., is Cracticus torquatus (Lath.) (Vanga destructor, Tem.).

Ardes maculata, Lath., is Nycticorax calcdonica, young.

Besides the above there are several other species which Latham originally described from these drawings, but which, having been long since identified and made known to naturalists, it is unnecessary to enumerate.

XLVIII.-Notes on the Botany of Sicily. By Jomn BALl, B.A., M.R.I.A.

Havisg observed in a recent number of this Magazine a paper upon the Botany of Sicily, containing a list of species observed or recorded as belonging to that island, I have been induced to refer to some notes made during a very hasty 